A. Shkurykhin

\title{
SHADOW LABOR MARKET ANALYSIS WITHIN COMPUTABLE GENERAL EQUILIBRIUM MODEL OF UKRAINIAN ECONOMY
}

\begin{abstract}
In pursuit of creating the tool for policy analysis accounting for existence of Ukrainian shadow econo$m y$, the shadow untaxed labor market is integrated into the aggregated static Computable General Equilibrium model. The developed model is successfully calibrated to official statistical data and proven suitable for further analysis. The efficiency of the 2016 social security tax reform is assessed and proven to be more dependent on the preferences between the formal and informal labor of the factor owner than on the magnitude of the tax cut. The importance of the preferences of both the manufacturer and the consumer, being represented as the elasticities of transformation and substitution between the formal and the informal labor in the model, is discovered. Based on treating these elasticities as instrumental variables, policy recommendations are developed.
\end{abstract}

Keywords: shadow labor market, computable general equilibrium, elasticity of substitution, elasticity of transformation, social security tax.

\section{JEL classification: C68, D58, E62}

Introduction and Research Problem. Shadow sector is undoubtedly a significant part of the Ukrainian economy, and this fact should be considered during design and evaluation of the public economic policy. Computable General Equilibrium family of models is generally considered a useful tool for public policy design and evaluation of its consequences. A properly designed and calibrated model allows for multiple scenario counterfactual analysis with virtually no additional effort, and with passage of time requires just recalibration to the changed initial conditions. The disadvantage of the majority of existing models is their ignorance of shadow economy existence, which might significantly affect the results of the policy measures and absorb the predicted effects, so they will not be reflected in the official macroeconomic statistics, leading to incorrect policy evaluation. Therefore, it is crucial to develop the widely recognized prediction framework suitable for fiscal, monetary and trade policy analysis, such as Computable General Equilibrium, and specifically account for shadow economy within the chosen instrumentation.

Recent Publications Analysis. Computable General Equilibrium models have been used to assess the consequences of serious shifts in Ukrainian economic policy; for instance, a highly disaggregated static model was employed to evaluate the economic impact of World Trade Organization accession in a prominent research by (Pavel, Burakovsky, Selit- ska, \& Movchan, 2004). Dynamic stochastic family of models, such as presented in (Lukyanenko \& Semko,2010) and (Lukyanenko \& Semko, 2012) are used for a more advanced analysis of economic dynamics including the concepts of intertemporal preferences and long-term growth trajectories. Partial and general equilibrium model also have been adjusted for the study of corruption in (Polonskii, 2009) and shadow economy (Vynnychuk \& Ziukov, 2013).

Unsolved Parts of the Problem. While there exist sophisticated models of Ukrainian economy with a sufficient degree of disaggregation, as well as simple models accounting for shadow economy, there is no intersection of these two approaches. Therefore, in order to obtain a well-designed model, it is necessary to start with the schematic comparative static setup, which allows for easier and more detailed disaggregation than dynamic stochastic family of models. As the shadow economy research generally lacks reliable data, static model is also preferable to dynamic one as it is less dependent on the quantity and quality of the initial state data used for calibration.

Purpose and Objectives of the Research. The research is devoted to the design, creation, calibration, testing and using for sensitivity and counterfactual analysis of the static Computable General Equilibrium model for the Ukrainian economy, which will specifically account for shadow econo- 
my in the form of shadow labor market. Informal labor is treated as a factor of productivity alongside with the formal labor and capital, but different as it is omitted from taxation process. The proposed model is created within General Algebraic Modeling System (GAMS) with the aid of Mathematical Programming System for General Equilibrium (MPSGE), similar to the approach outlined in (Markusen, 2002). The main objectives of the research are:

1) To design the model and to validate its suitability by calibration to macroeconomic data and check of the ability to recreate initial conditions;

2) To test the model ability of policy assessment by studying the consequences of Ukrainian social security taxation reform which took place in 2016 ;

3) To test the sensitivity of the solution obtained to the values of exogenous parameters in order to assure the assumptions about their possible range;

4) To find the most effective policy measures to be taken with awareness of shadow economy existence by running counterfactual experiments with different values of instrumental variables.

Main Findings. The Computable General Equilibrium model of the Ukrainian economy is developed as an extension of the basic model featuring one representative manufacturer and one representative consumer. The manufacturer is producing the Gross Domestic Product using two factors - labor and capital, and utilizing a Cobb-Douglas production function, which is the specific case of the constant elasticity of substitution function with the elasticity of substitution between factors equal to unity. The consumer is the owner of the production factors, and the proceeds from these factors' sale to the manufacturer form the consumer's budget constraint. The consumer spends the income to purchase the good produced by the manufacturer. Both economic agents optimize their behavior: the manufacturer minimizes the cost function while the consumer maximizes the utility function subject to budget constraint. The markets of the good and factors clear through the mechanism of flexible prices.

For the sake of simplicity, taxation is introduced as the system of transfers directly from the manufacturer to the consumer, omitting the centralized redistribution body. In this setup, taxes are treated as advalorem to factor usage; therefore, in the model tax on capital resembles corporate tax, and tax on labor resembles social security payments.

The principal change from the basic model is the split between formal and informal labor as production factors; they both belong to the customer and are utilized by the manufacturer, but only one of them is taxed. Shadow labor sector is then modeled as a dummy manufacturer, which uses total labor supply to produce formal and informal labor in order to provide as factors to the manufacturer. The consumer's choice whether to provide the formal or informal labor is modeled by the elasticity of transformation parameter in the constant elasticity of transformation production function of the dummy labor manufacturer. The higher is the value of the elasticity, the more untaxed labor is treated as the perfect substitute for the formal labor.

The proposed model is calibrated to the Ukrainian national accounts data for the third quarter of 2015, retrieved from (Derzhavna sluzhba statystyky Ukrainy, 2016). The share of the informal labor and the elasticity of transformation between the formal and the informal labor are treated as exogenous parameters and the sensitivity of the model to changes in them is tested during the calibration stage, when the ability of the model to reproduce the exogenous data and to form a baseline scenario. As shown in Table 1, the modified model with zero informal labor sector is identical to the generic one and exactly reproduces the input data; and the model output is indifferent to the value of the elasticity parameter under constant informal labor share. This indifference, which also holds at any fixed level of the informal labor share, is explained by the fact that unless the manufacturer (who is the principal taxpayer in the model) does not distinguish between the formal and informal labor, the consumer will supply the fixed amount of both independent of the preferences in order to maximize the consumption utility.

Table 1. Baseline scenario and indifference to the elasticity of transformation

\begin{tabular}{|c|c|c|}
\hline $\begin{array}{c}\text { Informal labor } \\
\text { share }\end{array}$ & $\begin{array}{c}\text { Elasticity } \\
\text { of transformation }\end{array}$ & $\begin{array}{c}\text { Gross Domestic } \\
\text { Product, UAH }\end{array}$ \\
\hline 0 & not available & 555044 \\
\hline 0.000001 & 100 & 555043.798 \\
\hline 0.000001 & 10 & 555043.798 \\
\hline 0.000001 & 1 & 555043.802 \\
\hline 0.000001 & 0.1 & 555043.805 \\
\hline
\end{tabular}

Holding the elasticity of transformation constant, which is allowed by the discovered indifference, the relationship between the share of the informal labor (modeled as a percentage of formal labor) and the share of informal gross domestic product is discovered: for each $1 \%$ of the labor being employed in the informal sector, the unaccounted gross domestic product equals $0,35 \%$ of the official national accounts data.

Given the discovered relationship, it is possible to calibrate the modified model to the shadow economy data and to fix the informal share parameter 


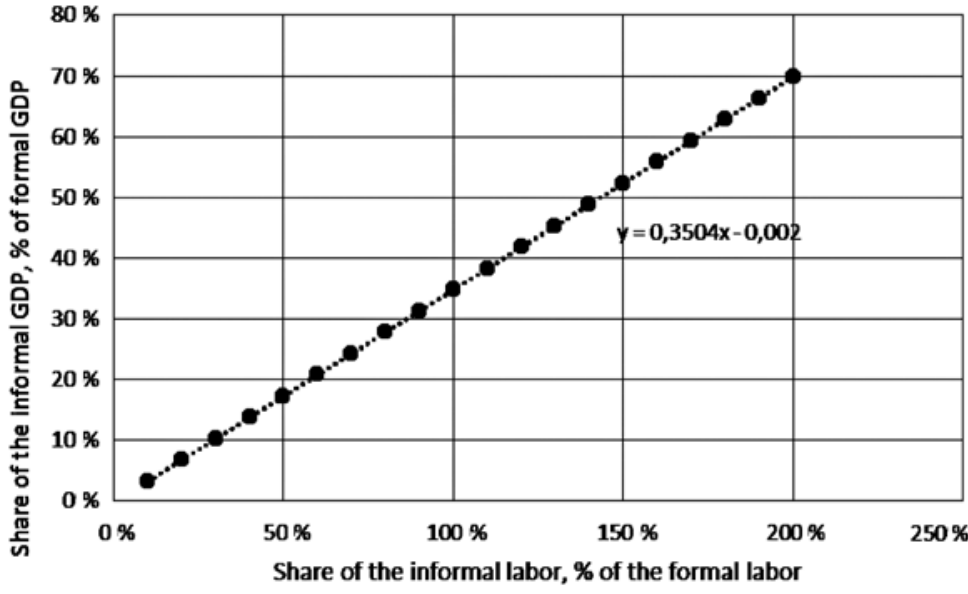

Fig. 1. Relationship between the share of the informal labor and the share of the unaccounted gross domestic product

nario and zero taxation marginal case, as shown in Table 2.

As the analysis suggests, the highest possible outcome from the tax cuts is the achievement of $0.24 \%$ growth and $5.67 \%$ contraction of the informal labor proposition, measured in units irrelative of factor prices, which is provided by the marginal case scenario of zero labor taxation that is indifferent to the elasticity of transformation value for the same reason as the results are indifferent for the same reason as obtained on the calibration stage. Under the implemented $55 \%$ rate shortening, comparable levels can be achieved

on the justified level. The latest official estimation (Departament ekonomichnoi strategii ta makroekonomichnogo prognozuvannya, 2016) suggests the production of the shadow economy equals to $40 \%$ of the officially calculated gross domestic product. Therefore, the parameter of the informal labor share is calibrated to $114.726 \%$ of the formal labor, which is interpreted as roughly $53 \%$ of the labor income in Ukraine is untaxed and therefore considered informal.

The calculated figure is obviously large and this magnitude of informal labor sector leads to the sufficient difficulties in government finance. To address this issue, Ukrainian government has implemented a cut in social security task by approximately $55 \%$ with the aim of shadow labor market contraction and balancing the budget of social security funds. The outcomes of the tax reform are analyzed under different assumptions about the elasticity of transformation and compared to baseline sce- only if the elasticity of transformation between formal and informal labor approaches zero, meaning the consumer treats the alternatives as nearly perfect complements. In case the alternatives are treated as substitutes, the efficiency of the cuts diminishes rapidly. Therefore, in order to achieve economic growth, it is more important to influence the perception of the choice between formal and informal labor market by the households then to introduce higher cuts. Last but not least important, the prices of the formal and informal labor units equal only in the cases of zero taxation and zero elasticity of transformation, which makes the manufacturer to choose between the two alternatives in general case.

In order to model the manufacturer's choice, the nested production function is introduced: on the first level, the manufacturer combines formal and informal labor using constant elasticity of substitution function, and then uses the aggregated labor in a

Table 2. Results of social security tax reform simulations

\begin{tabular}{|l|c|c|c|c|c|c|}
\hline \multicolumn{1}{|c|}{ Scenario } & $\begin{array}{c}\text { Formal labor } \\
\text { level, \% }\end{array}$ & $\begin{array}{c}\text { Informal labor } \\
\text { level, \% }\end{array}$ & $\begin{array}{c}\text { Price Index, } \\
\text { \% }\end{array}$ & $\begin{array}{c}\text { Price per unit } \\
\text { of formal labor }\end{array}$ & $\begin{array}{c}\text { Price per unit } \\
\text { of informal labor }\end{array}$ & $\begin{array}{c}\text { Real GDP growth, } \\
\text { \% of baseline }\end{array}$ \\
\hline Baseline & 100,00 & 100,00 & 100,00 & 3,019 & 2,638 & 0,00 \\
\hline $\begin{array}{l}\text { Zero taxation, } \\
\text { elasticity } \\
\text { insignificant }\end{array}$ & 108,12 & 94,33 & 99,76 & 2,797 & 2,797 & 0,24 \\
\hline $\begin{array}{l}\text { Tax reform, } \\
\text { elasticity 100 }\end{array}$ & 99,07 & 101,01 & 99,95 & 3,049 & 2,609 & 0,05 \\
\hline $\begin{array}{l}\text { Tax reform, } \\
\text { elasticity 10 }\end{array}$ & 99,77 & 100,40 & 99,91 & 3,027 & 2,624 & 0,09 \\
\hline $\begin{array}{l}\text { Tax reform, } \\
\text { elasticity 1 }\end{array}$ & 103,48 & 97,57 & 99,86 & 2,921 & 2,7 & 0,14 \\
\hline $\begin{array}{l}\text { Tax reform, } \\
\text { elasticity 0,1 }\end{array}$ & 107,19 & 94,94 & 99,76 & 2,819 & 2,779 & 0,24 \\
\hline $\begin{array}{l}\text { Tax reform, } \\
\text { elasticity 0,01 }\end{array}$ & 108,12 & 94,13 & 99,76 & 2,799 & 2,795 & 0,24 \\
\hline
\end{tabular}


familiar Cobb-Douglas production process. The relationship between the manufacturer's elasticity of substitution between the formal and informal labor and the gross domestic product growth over the baseline scenario of $55 \%$ social security tax cut under nearly perfect substitutes perception of the choice between the formal and the informal labor by the consumer (elasticity of transformation is equal to 100) is depicted on Fig. 2 and Fig. 3. It is shown that while the alternatives are treated as imperfect substitutes, the outcome of the tax cut is opposite to the expected, leading to the fall in gross domestic product up to $4.15 \%$. This happens due to partial shift of the manufacturer to the informal labor, which lowers the price of the formal labor because of its excessive supply (even despite the high elasticity of transformation of the factor owner) - and this combined with the fall in tax proceeds leads to fall in the consumer's budget endowments.

When the elasticity of substitution surpasses the critical point, which is calculated to be nearly 16.53 under the assumption of the baseline scenario,

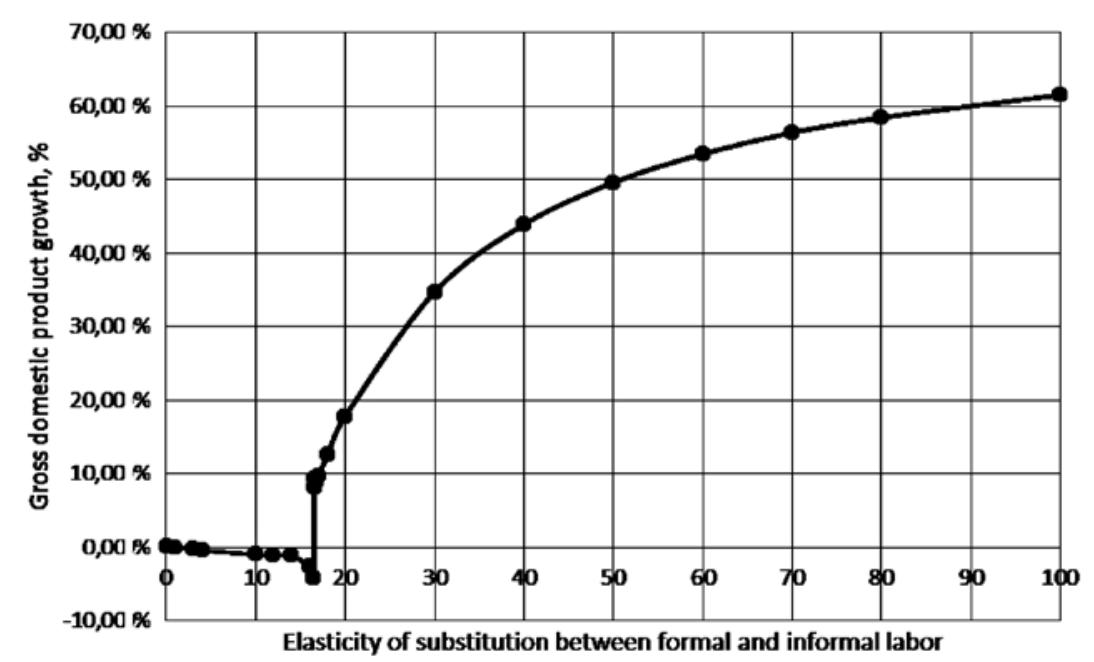

Fig. 2. Relationship between the manufacturer's elasticity of substitution and economic growth

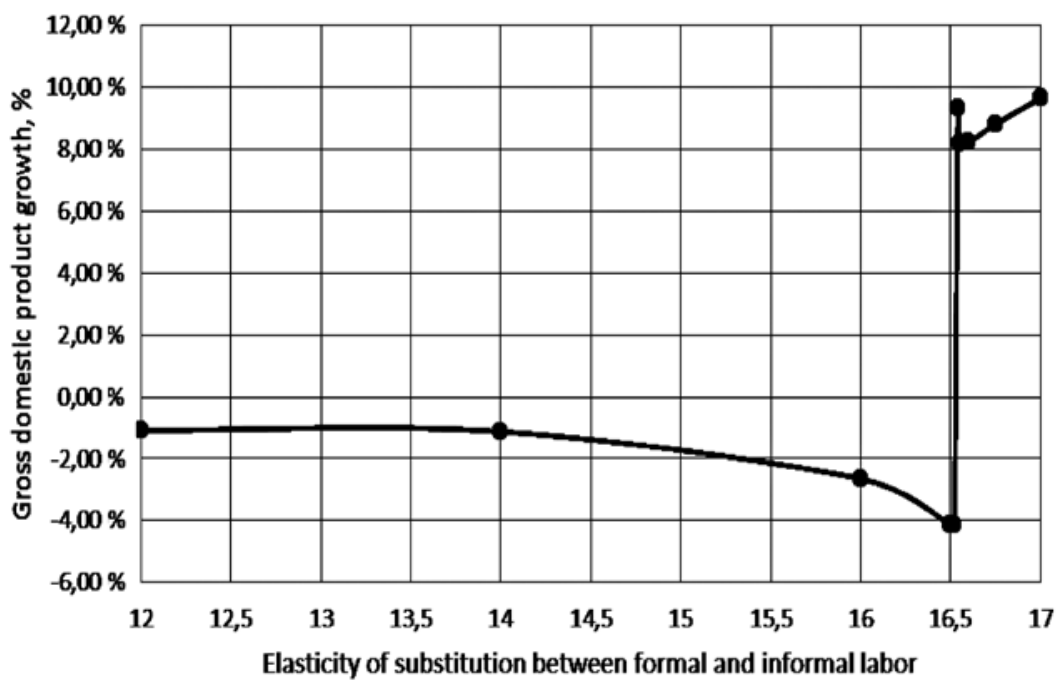

Fig. 3. Relationship between the manufacturer's elasticity of substitution and economic growth (critical point magnified) the choice of the manufacturer

strongly shifts to the less expensive informal labor leading to eventual decline in labor price and growth in total production. As the manufacturer's output is still taxed, the additional proceeds from the corporate profit tax exceed the loss of the consumer's factor income, leading to increasing consumption matching the increased production, and thus to real gross domestic product growth.

By testing the scenarios with lower elasticity of transformation, it is expectedly discovered that higher growth of gross domestic product (at the magnitude of about $8.5 \%$ over the critical point scenario's $9.35 \%$ growth) can be reached if the value of the elasticity of transformation falls below unity, as the rigidity to supply cheaper informal labor keeps the share of shadow labor constant and does not allow for sharp wage decline, and thus growing consumption allows the manufacturer to operate even with the increased factor costs.

The results of the computable general equilibrium model's counterfactual simulation provide strong evidence of the importance of the values of elasticity parameters describing the economic agents' relative preferences. It can be concluded that while designing the tax cuts, the consumer's elasticity of transformation between formal and informal labor is more important than the magnitude of the reduction. The anticipated growth consequences greatly depend on the manufacturer's elasticity of substitution between formal and informal labor; and only in the limited range of these two elasticities the desired growth can be achieved.

Conclusions and Further Research Suggestions. From the point of view of public policy, it can be concluded that without correct estimation of 
elasticities describing agents' choice between formal and informal labor, the goals of the implemented tax cuts will be difficult to reach. On the other hand, direct influence on the perception of choice parameters is shown to be more effective than fiscal measures. For the better results in anti-shadoweconomy policy it is necessary to make the manufacturer treat formal and informal labor as perfect substitutes, and the consumer - as perfect complements. These goals can be reached via:

1) Shift of the social security taxation from the employer to the employee and, generally speaking, abolishment of the employer's role as the tax agent along with removal of the controlling bodies' pressure.

2) Introduction and enforcement of personal income declarations and tax payments of physical entities.

3) Gradual pension system reform aiming at personal and not solidary social transfers.
4) Monetization of subsidies as well as other social protection programs, and their direct payments to the citizens.

5) Effective budget spending visible to the taxpayers.

From methodological point of view, even the schematic aggregated computable general equilibrium model has proven itself as a versatile tool for the policy analysis allowing for economywide effects estimation and advanced sensitivity analysis. The proposed model should be further disaggregated to account for different production sectors, international trade, household heterogeneity and the government as central redistributing agent. Provided a decent level of disaggregation and including the shadow economy description, it ought to construct better policy analysis than existing models describing only the formal economy.

\section{References}

1. Departament ekonomichnoi strategii ta makroekonomichnogo prognozuvannya. (2016, February 11). Tendentsii tinyovo ekonomiky Ukrainy u sichni-veresni 2015 roku [Ukrainian Shadow Economy Tendencies in January - September 2015]. Ministry of Economic Development and Trade. Retreived from: http://www.me.gov.ua/Documents/Download?id=5cee93d107dd-4d66-bd8b-98754ded9423.

2. Derzhavna sluzhba statystyky Ukrainy. (2016, January 19). Zvedeni natsionalni rahunky za III kvartal 2015 roku [Combined national accounts for the third quarter of 2015]. Retrieved from http://www.ukrstat.gov.ua/operativ/operativ2015/vvp/kvznr/ kvznr III 2015 u.zip.

3. Lukyanenko, I. G., \& Semko, R. B. (2010). Osoblyvosti pobudovy dynamichnoi stohastychnoi modeli zagalnoi rivnovagy dlya analizu ekonomiky Ukrainy [Specifics of Creating the Dynamic Stochastic General Equilibrium Model for Analysis of Ukrainian Economy]. Economic Cybernetics, 4-6 (64-66), 48-59.
4. Lukyanenko, I. G., \& Semko, R. B. (2012). Forecasting the Consequences of Economic Policy with General Equilibrium Model. Actual Problems of Economics, 1, 303-319.

5. Markusen, J. (2002). General-Equilibrium Modeling using GAMS and MPS/GE: some basics. MPSGE. Retrieved from http:// www.mpsge.org/tutorial.pdf.

6. Pavel, F., Burakovsky, I., Selitska, N., \& Movchan, V. (2004). Economic Impact of Ukraine's WTO Accession. First results from a Computable General Equilibrium Model. Kyiv: Institute for Economic Research and Policy Consulting.

7. Polonskii, G. (2009). Corruption and shadow economy: evidence from Ukraine and Russia. Kyiv: KSE, Unpublished master's thesis.

8. Vynnychuk, I., \& Ziukov, S. (2013). Shadow Economy in Ukraine: Modelling and Analysis. Business Systems and Economics, 3 (2), 141-152.

Шкурихін А. О.

\section{АНАЛІЗ ТІНЬОВОГО РИНКУ ПРАЦІ В МОДЕЛІ ЗАГАЛЬНОЇ РІВНОВАГИ ДЛЯ ЕКОНОМІКИ УКРАЇНИ}

3 метою створення інструменту для аналізу наслідків економічної політики з урахуванням існування значного тіньового сектора в Украйні, тіньовий неоподатковуваний ринок праиі введено до агрегованої статичної моделі загальної рівноваги. Розроблену модель успішно відкалібровано до офіційних статистичних даних та визнано придатною для подальшого аналізу. Очінено ефективність реформи єдиного соиіального внеску, запровадженої у 2016 р., та доведено більшу залежність результатів від переваг власника фактора прачі між формальним і тіньовим прачевламтуванням, аніж від обсягу зниження податку. Віднайдено важливість уподобань як виробників, так і споживачів у виборі між офіційним та неоподатковуваним ринком праці, виражена в моделі у значеннях еластичностей трансформації та заміщення між формальною те неформальною працею. Розроблено рекомендації до впровадження економічної політики, щьо базуються на трактуванні згаданих еластичностей як інструментальних змінних.

Ключові слова: тіньовий ринок праці, моделювання загальної рівноваги, еластичність заміщення, еластичність трансформації, єдиний соціальний внесок. 